NBER WORKING PAPER SERIES

\title{
CLOSED JAGUAR, OPEN DRAGON: COMPARING TARIFFS IN LATIN AMERICA AND ASIA BEFORE WORLD WAR II
}

\author{
Michael A. Clemens \\ Jeffrey G. Williamson \\ Working Paper 9401 \\ http://www.nber.org/papers/w940 \\ NATIONAL BUREAU OF ECONOMIC RESEARCH \\ 1050 Massachusetts Avenue \\ Cambridge, MA 02138 \\ December 2002
}

Presented to the Latin American and Caribbean Economic Association (LACEA) Conference, Madrid, October $11-13,2002$. This paper is one in a series of four written on global tariff history with various collaborators. In particular, the paper draws extensively on a Latin American tariff paper written by Williamson with John Coatsworth, and on a world tariff paper written by the current authors with Christopher Blattman, both of whom we are pleased to thank publicly. We have also received superb research assistance from Martin Kanz and István Zöllei. In addition, we are grateful to the many who have helped in our search for the country tariff and other data used in this paper: Luis Bertola, Alan Dye, Bouda Etemad, David Feeny, Aurora Gomez, Paul Gregory, Pedro Lains, Peter Lindert, Ian McLean, Anna Maria Mayda, Sevket Pamuk, Dwight Perkins, Gunnar Persson, Leandro Prados, Paul Rhode, Athanasios Vamvakidis, and Tarik Yousef. We have benefitted from comments from Graciella Marquez Colin, Richard Cooper, Ron Findlay, Jeff Frieden, Steve Haber, Tim Hatton, Elhanan Helpman, Doug Irwin, José Antonio Ocampo, Dani Rodrik, Dick Salvucci, Ken Sokoloff, Alan Taylor and seminar participants at the Harvard IADB Conference on Economic Integration in the Americas, the Dublin Conference on the Political Economy of Globalization, the Harvard Economic History Workshop, and seminars at the Universidad de la República (Uruguay). Remaining errors belong to us. Williamson acknowledges with pleasure financial support from the National Science Foundation SES-0001362, and Clemens acknowledges the support of the Center for Global Development. The views expressed herein are those of the authors and not necessarily those of the National Bureau of Economic Research.

(C) 2002 by Michael A. Clemens and Jeffrey G. Williamson. All rights reserved. Short sections of text not to exceed two paragraphs, may be quoted without explicit permission provided that full credit including, (C) notice, is given to the source. 
Closed Jaguar, Open Dragon: Comparing Tariffs in

Latin America and Asia before World War II

Michael A. Clemens and Jeffrey G. Williamson

NBER Working Paper No. 9401

December 2002

JEL No. F1, N7, O1

\begin{abstract}
Despite an enormous literature that has analyzed the comparative experiences of Latin America and Asia in post-World War II trade policy, almost no attention has been paid to the comparative experience prior to the wars. Even a cursory look at the best available empirical evidence reveals tremendous contrasts between the two regions. Latin America had the highest tariff barriers on earth before 1914; Asia had the lowest. Protected Latin America's belle époque also boasted some of the most explosive growth performance on earth, while Asia registered some of the worst. What brought the two regions to the opposite ends of the tariff policy spectrum? And why are these quantum differences in economic performance so at odds with postwar conventional wisdom? We begin by describing a novel tariff database we have constructed from largely original sources. We explore the impact of colonial rule and "unequal treaties" on Asian tariffs, as well as the impact of geography and political economy on Latin American tariffs. Limits to tariff policy autonomy explain one third of the vast difference between the two regions' tariffs before 1914; differences in the extent and structure of internal markets as well as the world tariff environment explain much of the rest. We conclude with an agenda for the future.
\end{abstract}

Michael A. Clemens

Center for Global Development

1776 Massachusetts Ave. NW, Suite 301

Washington, D.C. 20036-1909

mclemens@cgdev.org
Jeffrey G. Williamson

Department of Economics

Harvard University

Cambridge MA 02138

and NBER

jwilliam@kuznets.harvard.edu 


\section{Introduction}

The collected pages written on the Latin American and Asian experience with trade policy after World War II, if laid end to end, might well stretch from Guayaquil to Guangzhou. Almost no attention, however, has been paid to their comparative experience prior to 1940 . Even a cursory look at the best available empirical evidence reveals tremendous contrasts between the regions that cry out for explanation. Latin America had the highest tariff barriers on earth before 1914; Asia had the lowest. Protected Latin America's belle époque also boasted some of the most explosive growth performance on earth, while Asia registered some of the worst. What brought the two regions to the opposite ends of the tariff policy spectrum? And why are these quantum differences in economic performance so at odds with postwar conventional wisdom? The present work is a first step in exploring these important questions.

We begin by describing a novel tariff database we have constructed from largely original sources. We explore the impact of colonial rule and "unequal treaties" on Asian tariffs, as well as the impact of geography and political economy on Latin American tariffs. We conclude by measuring the relative contributions of different factors to the tariff divide between the two regions, and open a discussion of how these results might help illuminate the otherwiseunexpected positive tariff-growth relationship during this period.

\section{The Tariff Data}

A well-developed international literature makes it clear that trade shares are very poor measures of openness since they are endogenous and can be driven by demand and supply factors within countries which are completely independent of trade policy (e.g., Anderson and Neary 
1994; Sachs and Warner 1995; Anderson 1998). ${ }^{1}$ Among the explicit policy measures of openness available, the average tariff rate is by far the most homogenous protection measure and the easiest to collect across countries and over time. We are, of course, aware that countries can have the same average tariff levels, but very different tariff structures reflecting very different intent. We are also aware that by the 1930s every country had learned how to use non-tariff barriers (NTBs), especially the manipulation of the real exchange rate to favor import competing industries. But NTBs were not used before the 1920 s, and pretty much every country was on a fixed exchange standard before World War I and again by the late 1920s. In short, tariffs were the main instrument of trade policy before the 1930s. Thus, it seems to us that as an overall measure of protection, average tariffs are the place to start any empirical analysis of the political economy of protection. In addition, while high tariffs may not necessarily be the result of explicit protectionist goals, high tariffs are still protectionist whatever the intent.

This paper uses the computed average tariff rate to explore differences between Asian and Latin American policy experience from shortly after the mid- $19^{\text {th }}$ century to World War I. Our country observations from these two regions are part of a larger world sample of 35 , extending up to 1950: the United States; 3 members of the European industrial core (France, Germany, United Kingdom); 3 non-Latin European offshoots (Australia, Canada, New Zealand); 10 from the European periphery (Austria-Hungary, Denmark, Greece, Italy, Norway, Portugal, Russia, Serbia, Spain, Sweden); 10 from Asia and the Mideast (Burma, Ceylon, China, Egypt, India, Indonesia, Japan, the Philippines, Siam [Thailand], Turkey [Anatolia]) and 8 from Latin America (Argentina, Brazil, Chile, Cuba, Colombia, Mexico, Peru, Uruguay). Standard tariff histories focus mainly on eight of these - Denmark, France, Germany, Italy, Sweden, the United Kingdom and the United States. We think this big world imbalance needs to be redressed, so

\footnotetext{
${ }^{1}$ Indeed, it appears that fully two-thirds of the late $20^{\text {th }}$ century trade boom involving the OECD can be explained by unusually fast income growth, not by the decline in trade barriers (Baier and Bergstrand 2001). To cite another example, it also appears that two-thirds of the European overseas trade boom in the
} 
what follows will focus on the 10 Asian and 8 Latin American countries in our sample that represent the non-European periphery. ${ }^{2}$

Average tariff rates are calculated as the total revenue from import duties divided by the value of total imports in the same year. In some cases, the sources used do not distinguish between import and export duties, and report only total customs duties. Total customs duties (instead of import duties) are used in the calculation of average tariff rates only for countries where the value of export duties has historically been an insignificant share of total customs duties. Sometimes, the value of import duties collected is reported for fiscal years, while import data generally refer to calendar years. While making a consistent effort to compare calendar year duties to calendar year import values, in cases where calendar year duties figures are unavailable, fiscal year duties are divided by calendar year imports to calculate average tariff. In these instances, fiscal year import duties are assumed to belong to the calendar year in which most of the fiscal year falls. ${ }^{3}$

To emphasize, the remainder of this paper defines "Latin America" as the eight-country sample consisting of Argentina, Brazil, Chile, Colombia, Cuba, Mexico, Peru, and Uruguay. "Asia" is defined as the ten-country sample consisting of Burma, China, Ceylon, Egypt, India, Indonesia, Japan, the Philippines, Siam, and Turkey, while "East Asia" is defined by the subsample of China, Indonesia, Japan, the Philippines, and Siam.

three centuries following 1492 were also driven by income growth, rather than by any decline in trade barriers (O'Rourke and Williamson 2002).

${ }^{2}$ Elsewhere, this project has explored Latin America (Coatsworth and Williamson 2002) and will explore the European periphery, that is, Iberia, Italy, the Balkans, eastern Europe, and Russia (Clemens, O'Rourke and Williamson ongoing). 


\section{Defining Tariff Autonomy}

Our empirical analysis requires formalization of the concept of "tariff autonomy," the freedom to set tariff levels independent of another state's military and political power. Table 1 documents the years in which we construe each country under study to have tariff autonomy. Burma, Ceylon, and India were subject to British imperial tariff collection policies, as Cuba was to the Spanish through 1899 and Indonesia (Netherlands Indies) was to the Dutch. The British Foreign Office in China largely eliminated the tariff restrictions imposed by the treaties of Nanking and Tientsin in 1929. Norway did not have an independent tariff policy under the Swedish crown through 1905. Gradual weakening of Ottoman control in Serbia is construed to imply tariff autonomy following the 1878 Treaty of Berlin. Egypt is taken to hold tariff autonomy under noninterventionist Ottoman rule during the years prior to the British invasion of 1882, but not thereafter. Thailand is taken to recover autonomy from the grasp of the unequal treaties in 1891 (Ingram 1971: p. 138). We take Turkey to have lost tariff autonomy in the brief years between its defeat in World War 1 and Mustafa Kemal's establishment of the Turkish Republic.

With these definitions of tariff autonomy in mind, we turn to colonial tariff policy next, followed by tariff policy under gunboat diplomacy.

\section{Did Asian Colonies Simply Mimic Their Masters?}

This is a good place to explore the tariff autonomy issue within the colonies. There are five in our sample, all in Asia: Burma, Ceylon, India, Indonesia and the Philippines, although

\footnotetext{
${ }^{3}$ A complete appendix description of the sources and methods surrounding the tariff data base can be found in Clemens and Williamson (2002) and Blattman, Clemens and Williamson (2002).
} 
foreign influence was strong enough (including occupation) to make Egypt behave like a colony (Owen 1993: p. 122). To what extent did these six simply mimic their colonial masters?

Figure 1 reveals a clear correlation in timing and magnitudes of change in tariff rates between the UK and four (Burma, Ceylon, Egypt and India), and Figure 2 shows the same for the Philippines, first for Spain and then for the US (becoming the imperialist master in 1899). Table 2 reports the master-colony tariff rate correlations for these four and for the Philippines. ${ }^{4}$ Colonial tariff policy did indeed mimic that of the masters: although Spain failed to imprint its tariff rates on the Philippines before 1899 (Figure 2), the US did afterwards, and Britain did so across all four of its Asian colonies documented here (Figure 1). Furthermore, the t-statistics are very large and the slope coefficients are similar across masters and colonies, ranging between about 0.5 and 0.9 .

But note the variance across these four at any point in time (Figure 1), and note the country-specific variance in the intercepts reported for the five in Table 2: Philippine tariff rates were on average about 2 points below the US after 1898; and compared with Britain, India's were about the same, Burma and Ceylon were 4 or 5 points higher, and Egypt was 10 points higher. Clearly, local conditions mattered even in colonies. Thus, we retain the full Asian sample of 10 in all that follows, although we will take care to control for the tariff policy of the masters.

There are three surprises that emerge from this section. First, local conditions influenced tariff policy even in the colonies. For example, in the 1930s tariff rates ranged between $9.9 \%$ in the Philippines to $28.7 \%$ in Burma. Second, the colonies in Asia had higher tariffs than the "independents" elsewhere in Asia throughout the eighty years following 1870. For example, if we exclude Egypt and Turkey, in the 1890s colonies had 7.1\% tariff rates while "independents" had $3.8 \%$, and in the 1930 s colonies had $19.3 \%$ tariff rates while "independents" had $17.3 \%$. (See also Figure 3.) Third, tariffs rose to high levels everywhere in Asia during the 1930s,

\footnotetext{
${ }^{4}$ The Netherlands is not part of our sample, and thus we cannot explore the same correlations between it and Indonesia.
} 
including the colonies. This was long before the postwar independence moves to de-link from world markets by ISI strategies, and tariffs in Asia were by the end of the 1930s as high as they were in Latin America (Figure 4).

\section{Asian Gunboat Diplomacy Towards the "Independents"}

Independence did not necessarily mean tariff autonomy. Although our focus in this paper is tariff experience after the 1860 s, we must start a couple of decades earlier to deal with the issue of Asian tariff autonomy.

Transport costs dropped very fast before World War I, accounting for about two-thirds of the integration of world commodity markets over the century following 1820, and for all of world commodity market integration in the four decades after 1870, when globalization backlash offset some of it (Lindert and Williamson 2002). This political backlash was absent in Asia, partly because of the political influence wielded by natives who appear to have had at least some control over the natural resources that were the base of their exports, partly because many of the colonialists were free traders, and partly because many "independents" were persuaded to go open and stay open by gunboat diplomacy. As a result, commodity price convergence and trade creation between the Europe and Asia were even more dramatic than within the Atlantic economy (O’Rourke and Williamson 1999; Williamson 2002).

While the fall in transport costs was dramatic, it was not the greatest globalization event affecting $19^{\text {th }}$ century Asia. Under the duress of Commodore Perry's American gun ships, Japan signed the Shimoda and Harris treaties and in doing so switched from autarky to free trade in 1858 (Howe 1996: Chp. 30). It is hard to imagine a more dramatic switch in trade policy since Japan's foreign trade quickly rose from nil to 7 percent of national income, ${ }^{5}$ and its terms of trade

\footnotetext{
${ }^{5}$ This rise is computed over the fifteen years following 1858 (Huber 1971).
} 
improved by a factor ranging from 3.5 times (Huber 1971) to 4.9 times (Yasuba 1996). Between 1866 and 1895 the "unequal treaties" continued to limit Japanese tariffs to 5\% ad valorem (Lockwood 1968: pp. 18-19). Japan regained tariff autonomy in 1899, but "[e]ven the recovery of tariff autonomy in the nineties still left treaty restrictions on the duties applying to many items. Rates were generally no higher than 10 to $15 \%$ until the general tariff revision of 1911 ” (Lockwood 1968: p. 539).

Other Asian nations followed the same liberal path, most forced to do so by colonial dominance or gunboat diplomacy. Thus, and even before the Japanese humiliation, China signed a treaty with Britain in 1842 which opened her ports to trade. The treaties of Nanking (1843) and Tientsin (1858), as well as other similar treaties, limited the Chinese ad valorem tariff rate on imports from essentially all of Europe to 5\%. In fact, the treaties (and their revisions in 1870, 1902 and 1922) did not set ad valorem rates but rather nominal specific duties that, although initially equivalent to a $5 \%$ ad valorem tariff, rapidly declined in effective value as prices rose (Remer 1926: pp. 171-81). Siam avoided China's humiliation by going open on its own and adopting a 3 percent tariff limit in 1855 . Between 1865 and 1890 treaties with all the major powers kept import duties below 3\% in Siam (Ingram 1971: pp. 34-5). Only after 1890 did the Siamese government begin to revise the earlier treaties and increase its tariff revenue by raising its tariff rates (Ingram 1971: p. 138). Korea emerged from its autarkic Hermit Kingdom about the same time, undergoing market integration with Japan long before colonial status became formalized in 1910 (Brandt 1993; Kang and Cha 1996). India went the way of British free trade in 1846, and Indonesia followed Dutch liberalism. Thus, and in contrast with Europe and Latin America, sharply declining transport costs contributed to commodity price convergence in Asia without any offsetting rise in tariffs. 


\section{Some Latin American Belle Époque Surprises}

A recent collaborative paper involving one of the present authors (Coatsworth and Williamson 2002) uncovered some facts that have not been well appreciated. Tariffs in Latin America were far higher than anywhere else in the world during the decades before World War I, long before the Great Depression when the region retreated into what became known as an ISI strategy. Indeed, they were even rising in the decades before 1914, a period that has been called the first globalization boom for the world economy (O’Rourke and Williamson 1999). This fact is surprising, and for three reason. First, it comes as a surprise given that this region has been said to have exploited globalization forces better than most during the pre-1914 belle époque. Second, it comes as a surprise since standard economic histories say so little about it. Third, it comes as a surprise to most of us who have always been taught to view the Great Depression as the critical turning point when the region is said to have turned towards protection and de-linked from the world economy for the first time.

These Latin American surprises can be seen in Figure 4, but they can be appreciated even better by comparisons with the rest of the world. As we noted above, conventional wisdom is that Latin American reluctance to go open in the late $20^{\text {th }}$ century was the product of the Great Depression and the de-linking import substitution strategies that arose to deal with it (Diaz-

Alejandro 1984; Corbo 1992; Taylor 1998). Yet, $19^{\text {th }}$ century Latin America-whether the poor four (Brazil, Colombia, Mexico, Peru), the rich three in the southern cone (Argentina, Chile, Uruguay), or even Cuba - already had by far the highest tariffs in the world with the exception only of the US. For example, in 1885 the poor but independent parts of Latin America (Brazil, Colombia, Mexico and Peru) had tariffs 4.6 times higher than those in the poor and dependent parts of Asia (Burma, Ceylon, China, Egypt, India, Indonesia and the Philippines). Perhaps more to the point, in the decades before 1914 tariffs in Latin America were, on average, five times 
higher than those in the European industrial core (Britain, France and Germany; Coatsworth and Williamson 2002: Figure 2a)!

At the crescendo of the belle époque, Latin American tariffs were at their peak, and still way above the rest of the world. For example, in 1905 tariffs in Uruguay (the most protectionist land-abundant and labor-scarce country) were about two and a half times those in Canada (the least protectionist land-abundant and labor-scarce country). In the same year, tariffs in Brazil and Colombia (the most protectionist Latin American countries) were almost ten times those in China and India (the least protectionist in Asia). Furthermore, the rise in Latin American tariffs from the late 1860 s to the turn of the century was much steeper than was true of Europe, including France and Germany about which so much tariff history has been written. For example, the rise in the average tariff rate between the 1870 s and the 1890 s was 5.7 percentage points in France, up from 4.4 to still only 10.1 percent, and 5.3 percentage points in Germany, up from 3.8 to still only 9.1 percent. This heavily-researched continental move to protection is pretty minor when compared with the rise over the same period in the four poor Latin American countries (up 6.9 percentage points to 34 percent), and this for a region which has been said to have exploited the pre-1914 globalization boom so well by pursuing free trade policies, allowing exports to be an engine of growth!

\section{Closed Jaguar, Open Dragon?}

Figure 4 reveals the stark difference between Latin American and Asian tariff policy that persisted over the century between the 1860s and the Second World War. Black lines show regional means, while gray bands indicate one (regional) standard deviation above and below that mean.

Note the large dip in tariff rates across World War 1, a worldwide phenomenon due to the tendency for wartime inflation to erode the ad valorem equivalent of what were largely specific 
duties. Note also the tariff rate surge in the early thirties, spiking in 1933, again repeated across the globe, as prices fell, raising the ad valorem equivalent of those specific duties. Of course, tariff rates were also raised in response to America's Hawley-Smoot Act, so that tariff rates remained high in the late 1930 s after prices began to inflate during the recovery.

Why were specific duties so common in poor parts of the world? There are two possible explanations. First, honest and literate customs inspectors are scarce in poor countries, but honest and literate customs inspectors are needed to implement an ad valorem tariff where import valuation is so crucial. So, legislators impose specific duties to minimize the "theft" of state tariff revenues by dishonest and illiterate customs agents. Second, specific duties are more effective macro-stabilization devices in poor countries that rely so heavily on customs duties as a source of total government revenue. During booms, prices rise, lowering effective tariff rates, thus tending to mute the boom in tariff revenues generated by the boom in import demand. During slumps, prices fall, raising effective tariff rates, thus tending to offset the slump in tariff revenues generated by the slump in import demand. These macro-stabilization forces would be all the more valuable in pre-World War II Latin America and Asia when both regions were susceptible to great price instability in their commodity export markets.

Table 3 summarizes the variance in tariff rates before 1914. Variance was neither largely within nor largely between countries in each region. The average Latin American country had four times the tariff level of the average Asian country. Table 4 gives average tariffs for each country under consideration during three different time periods. Setting aside for a moment the relatively high tariffs of the Philippines, every Asian country had lower tariffs than every Latin country before 1914. That was not true after World War I, however, when three Asian countries nudged their tariff rates up in to Latin American ranges (Burma, Egypt, Turkey). And, to repeat, by the late 1930s Asia on average had higher tariffs than Latin America.

Figure 5 presents cross-sectional unweighted average GDP per capita, in 1990 US\$, for the two regions. The big morals of Figure 5 are, despite variation within the sample and interwar 
troubles, that Latin America started from a richer resource base and thus a higher per capita income, that her belle époque growth experience left Asia far behind, and that the GDP per capita gap between Latin America and Asia stopped widening in the interwar decades. Were high tariffs associated with fast growth? An answer is offered in Figure 6, which focuses on the years leading up to 1914. In the upper right of the figure, with enormous tariffs and impressive growth performance, lie all of the Latin countries under study. In the lower left lies a cloud of East Asian countries, with neither tariffs nor growth. The Philippines looks Latin as it makes the transition to American colonial rule, and the rest of Asia outside of Ceylon follows the East Asian pattern.

\section{Why Were Latin America and Asia So Different?}

Table 5 seeks to identify which differences in characteristics between Latin America and Asia might have underlain their vastly different tariff levels before 1914. The table estimates a worldwide model of cross-sectional differences between countries' tariffs, for 35 countries. These regressions use a panel between effects estimator, since the question we seek to answer is cross-sectional-Latin America versus Asia. The first three columns address the fact that coverage of the inflation regressor in our database is limited to 30 of the 35 countries. The first column thus analyzes the full sample, the second column includes the same regressors but restricts the sample to datapoints for which inflation is not missing, and the third column includes inflation. The last three columns, which are intended to address concerns of endogeneity bias, will be discussed below.

What do we expect? The right-hand side variables suggested by previous work (Coatsworth and Williamson 2002; Blattman, Clemens and Williamson 2002), and used in Table 5 , are the following (all but dummies in $\operatorname{logs}):^{6}$

\footnotetext{
6 A complete description of the right-hand side variables can be found in appendices to Clemens and Williamson (2002) and Blattman, Clemens and Williamson (2002).
} 
Export share. This export/GDP ratio is a measure of export boom, where we expect booms in the previous year to diminish the need for high tariff rates this year-if government revenues are the goal-thus yielding negative coefficients in the regression; ${ }^{7}$

$\underline{G D P}$ per capita, and $\underline{\text { Schooling, }}$, the latter the primary school enrollment rate. These variables are taken as proxies for skill endowments, with the expectation that the more abundant the skills, the more competitive the industrial sector, and the less the need for protection (at least in the Latin American and Asian peripheries where manufacturing was import competing), thus yielding a negative coefficient in the regression;

$\underline{\text { Population. }}$. Large countries have bigger domestic markets in which it is easier for local firms to find a spatial niche. Alternatively, larger populations also imply higher density, a fact that makes domestic tax collection easier and tariff revenues less necessary. In either case, the demand for protection should be lower in such countries, and the regression should produce a negative coefficient;

$\underline{\text { Partner Tariffs, }}$, measured as a weighted average of the tariff rates in the trading countries' markets, the weight being trade volumes, lagged. Strategic tariff policy (e.g., Dixit 1987; Bagwell and Staiger 2000) suggests that countries should have imposed higher tariffs this year if they faced higher tariffs in their main markets abroad last year;

$\underline{\text { Effective Distance. }}$. The distance from each country to either the US or the UK (depending on trade volume), that distance adjusted by seaborne freight rates specific to that route. If protection was the goal, effective distance should have served as a substitute for tariffs, so the regression should yield a negative coefficient;

\footnotetext{
${ }^{7}$ In related paper on Latin America involving one of the present authors (Coatsworth and Williamson 2002), capital inflows from Britain were added to the analysis for the years 1870-1913. This variable measured annual British capital exports to potential borrowing countries. Countries favored by British lending were shown to have had less need for tariff revenues and thus had lower tariffs. We do not add the variable here, since our source does not report the period 1914-1938.
} 
$\underline{\text { Railway Mileage }}$ added in kilometers. Poor overland transport connections to interior markets serves as a protective device. Railroads reduce that protection, requiring higher tariffs to offset the effect. Thus, the regression should yield a positive coefficient;

$\underline{\text { Urbanization, }}$ taken as share of population in cities and towns greater than 20,000 . We take this urbanization statistic to be a Stolper-Samuelson proxy for the lobbying power of urban capitalists and artisans in the periphery, thus yielding a positive coefficient in the regressions;

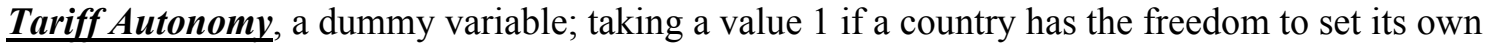
tariffs independently, and 0 otherwise. See Table 1;

Inflation and inflation-squared, the rates in home markets. To the extent that countries used specific duties, we expect inflation to lower tariff rates, thus yielding a negative coefficient. However, very rapid inflation might well have triggered a speedier legislative reaction with increases in specific duties, thus yielding a positive and offsetting coefficient on the squared term in the regression.

It appears that the regression model does well since all the coefficients in columns (a) and (c) take on their predicted signs and almost always pass significance tests. The coefficient of determination is likewise high for all specifications.

The model could nevertheless produce biased coefficients if tariffs have a causal effect on GDP per capita or on exports (this last through a direct effect on imports coupled with a balance of payments mechanism linking imports and exports). In columns (4) through (6) we see that dropping either GDP per capita or exports (or both) has only minor effects on the magnitude and statistical significance of the other coefficients. The only important change appears to occur in the coefficients on schooling - which, we will see below, cannot affect our substantive conclusions. In the case of GDP per capita, we have shown elsewhere (Clemens and Williamson 2002) that the correlation between tariffs and growth was positive before 1914; any endogeneity bias would therefore be in the positive direction, meaning that the unbiased coefficient could only be more negative than it already is. Since GDP per capita was higher in Latin America than in 
Asia, this means that any endogeneity bias to the coefficient on GDP per capita would only strengthen our conclusion that different levels of economic development were not per se responsible for the difference in tariffs between the two regions. The same is not true of export share in GDP, but Table 6 will show that excluding export share entirely does not affect our conclusions in the least. We run little risk, then, of reaching spurious conclusions due to endogeneity bias.

Together, the regressors we study can explain between $65 \%$ and $78 \%$ of cross-sectional tariff variation before 1914. Which of them can explain the cross-sectional difference between Latin and Asian tariffs during this period? Table 6 addresses this question. The first six columns of Table 6 are simply the coefficient estimates from Table 5, reproduced without modification. The next two columns give the average values of each regressor in both Latin America and Asia, in natural logarithm; at the bottom the same values for the regressand are shown. Of particular note is the similarity of the figures for effective distance, an average of physical distance to the top 5 trading partners weighted by exports sent to that partner, multiplied by an index of transportation costs. Asia may have been far away from the core, but it was doing more intraregional trading than Latin America. Latin America had a notably higher share of exports in GDP, a much smaller average population, much more railway penetration, and a much greater degree of tariff autonomy.

The final six columns are a linear combination of numbers from the previous columns. The result is an estimate of the relative contribution of each variable to the much higher pre-1914 tariffs in Latin America compared with Asia. It is calculated in the following way. First, we take the difference between the average regressor value in Latin America and its value in Asia, from columns (7) and (8). Second, this difference is multiplied by the corresponding coefficient from the first six columns. Third, this number is divided by the average difference in $\ln$ (Own Tariff) between the two regions during this period (the last row of columns (7) and (8)). The resulting ratio $\delta$ is an estimate of the relative contribution of each regressor to the observed fact that tariffs 
were much higher in Latin America than in Asia. A value of zero means that the regressor is not responsible for any of the difference. A negative value indicates that the regressor actually contributed to tariffs being lower in Latin America than in Asia, ceteris paribus. We are looking for large positive values in those last two columns.

Some potential explanations for the difference can be eliminated immediately. Thus, the export share in GDP and GDP per capita were higher in Latin America than in Asia, instead of being lower as they would need to have been in order to contribute to the observed tariff differential between the regions. Differences in effective distance or schooling rates also cannot explain the difference. The relative importance of the remaining explanators is not affected by the inclusion or omission of inflation, nor is it affected by the exclusion of the potentially endogenous regressors GDP per capita and export share of GDP.

The five that clearly mattered were population, railroads, urbanization, partner tariffs and tariff autonomy. Take the first three first, saving tariff autonomy and partner tariffs for last. Asia's enormous populations provided gargantuan internal markets in which producers could exploit specialization and scale. Large internal markets tended to diminish the need for tariffs to protect import-competing producers. Latin America's exploding railroad network increased access to that internal market, but it also exposed interior producers to more foreign competition, encouraging a tariff backlash to offset the impact of the railroads. The railroad system was less extensive in Asia, and in fact we have measured it in a fashion that understates the Asian railroad shortfall (miles of railway trunk line, rather than miles per capita). A less extensive railway system in Asia implied less need for tariffs for protective purposes.

Higher levels of urbanization in Latin America also help to explain the gap in tariff rates between Latin America and Asia. Ronald Rogowski (1989) has used the Stolper-Samuelson theorem to suggest that we look to Latin American urban capitalists for the political economy explanation for those extraordinarily high tariffs during the belle époque. Although their economies certainly varied in labor-scarcity, every Latin American country faced relative capital 
scarcity and relative land abundance. As the Stolper-Samuelson theorem has it, "protection benefits (and liberalization of trade harms) owners of factors in which, relative to the rest of the world, that society is poorly endowed" (Rogowski 1989: p. 3). According to this kind of thinking, urban capitalists should have been looking to form protectionist coalitions as soon as the Latin American belle époque and the pax britannica peace and growth began to threaten them with freer trade. High urbanization rates in Latin America gave these interests more power to achieve protection, while low rates in Asia contributed to the opposite result.

Even controlling for so many other factors, tariff autonomy was important. How much did it matter? After all, we have seen a variety of tariff rates even within colonies run by imperialists favoring free trade at home. Still, policy autonomy implied high tariffs before World War I, with the coefficient on the autonomy variable in the regressions ranging between 0.618 and 0.912 in columns (1) through (6). The model suggests, then, that granting tariff autonomy would have raised tariffs by a factor of between 1.7 and 2.5 , all else equal. ${ }^{8}$ In other words, the model indicates that granting late $19^{\text {th }}$ century Asia the same level of tariff autonomy as Latin America (changing it from 0.21 to 0.92 ) could have raised Asian tariffs from $7 \%$ to between $12 \%$ and $17 \%$. Turning to columns $\left(1^{\prime}\right)$ through $\left(6^{\prime}\right)$, we see that Asia's lack of tariff autonomy explains about one third — or perhaps a little more — of the difference between Asia and Latin America seen in Table 3.

Were the Asian countries subjected to "unequal treaties" but not formally colonies (China, Japan, and Siam) any less tariff-restricted than those that were colonies (Burma, Ceylon, India, Indonesia, and the Philippines)? No. In fact, they were more so, as Figure 3 documents.

With policy autonomy, Asian tariff levels might have been half those of Latin America, rather than a fourth. But, as we have seen, tariff autonomy was not the only factor at work. Internal market size mattered, as did the protection of the market that poor railroads offered domestic producers. Weak political power of the Asian urban capitalist mattered, a weakness 
associated with smaller urban presence there compared with Latin America. Finally, after controlling for tariff autonomy, partner tariffs mattered. If your trading partner had high tariffs, so did you. Since Latin America traded more with protectionist North America, while Asia traded more with free trade Europe (especially its free trade colonizers Britain and the Netherlands), more of the tariff rate gap between Latin America and Asia is explained.

We cannot leave thus section without saying a word about historical persistence, especially in the case of Latin America. Namely, our empirical work in Table 5 covers the decades after 1870 , but what about the half century before? Does it matter that this postindependence period was extremely violent?

In young, recently independent economies with low or even declining capacity to tax income, expenditure or wealth, few bureaucratic resources to implement efficient collection, and limited access to foreign capital markets, customs revenues are an easy-to-collect source essential to support central government expenditures on infrastructure and especially defense. This was certainly true of the newly-independent United States and Latin American countries in the first half of the $19^{\text {th }}$ century, although the US had more success in gaining access to European capital markets. The average share of customs duties in total revenues across eleven Latin American republics was 57.8 percent between 1820 and 1890 (Centeno 1997: Table 1). Furthermore, customs revenues are especially important for land-abundant countries with federal governments since they do not have the population and tax-payer density to make other forms of tax collection efficient. ${ }^{9}$ Now add to these facts a huge revenue need to fight wars and we emerge with the high United States tariffs during the civil war of the 1860s and the high (and rising) tariffs in the newly-independent Latin America republics that experienced almost continuous war and civil

\footnotetext{
${ }^{8}$ Since the dependent variable is in logs, $0.618 \times 2.72=1.68$ and $0.912 \times 2.72=2.48$.

${ }^{9}$ For federal governments, customs revenues were even bigger share of total revenues in Latin America (65.6 percent)
} 
conflict between the 1820s and the 1870s (Mares 2001; Centeno 1997; Coatsworth and Williamson 2002).

The preoccupation with national defense and internal security pushed the newly independent Latin American republics toward higher revenue-maximizing tariffs. Military expenditures quickly rose to consume over 70 and often more than 90 percent of all revenues (Centeno 1997). Weak governments, under attack from within and without, abandoned internal taxes that required an extensive and loyal bureaucracy to collect and concentrated tax collection efforts instead on a few ports and mines. Thus, levels of "protection" rose in every Latin American country (for which there are data) as did the customs revenues as a percentage of total government revenues.

We stress these facts since we believe historical persistence matters and that some part of those very high Latin American tariffs between 1870 and World War I can be explained by the level of violence in the half century before 1870, violence so particular to Latin America during what was otherwise a pax britannica world.

\section{Concluding Remarks}

The simple pre-1914 correlation between tariffs and growth documented in Figure 6 starkly reverses if one considers instead the years after 1976. Over the early period, Latin America recorded GDP per capita growth rates four to five times that of Asia, and had tariff rates five times as high. Over the more recent period, China, Indonesia, Thailand and Japan experienced GDP per capita growth rates between 3 and 8 percent per annum with tariffs well below 10 per cent, while Argentina, Colombia, Peru and Uruguay had about double the tariff levels but grew at 2 percent per annum or less. Why the change in correlation?

In another work (Clemens and Williamson 2002) the authors provide empirical evidence suggesting that this switch, which is robust to inclusion of all 35 countries in the sample, may 
have been influenced by unilateral tariff reductions following World War II in the world's most important trading economies. That is, before 1914 when the United States had extraordinarily high tariff barriers, it may have been advantageous for any Latin American country, trading significantly with the US, to retaliate with similarly high barriers. And before 1914, when European industrial powers had low tariff barriers, it may have been advantageous for any Asian country to keep their own tariffs low, especially if their trade was with Britain, the Netherlands and other free traders. This was, after all, the revealed preference of most Asian nations: while raising tariffs upon shaking off "unequal treaties" before World War I, they did not raise them by much until the 1930s. Certainly the relative change was large, suggesting that the treaties had done harm — both Japan and Thailand went from below 5\% tariffs to around 10\% as the treaties were lifted-but the absolute rise was not so large. The Latin American policy choices were apparently not harmful to growth. In contrast, after 1950, choosing isolation from the newly freetrading, rich OECD nations, undergoing a postwar growth miracle, appears to have been harmful to growth.

Our purpose here, however, is not to prove that a similar mechanism was responsible for the unaccustomed patterns of tariffs and growth we observe in Latin America and Asia before 1914. For the present we are content merely to document the vast pre-1914 tariff policy gap between the two regions and to suggest that the present is deeply rooted in the past. Still, we think it is fair to raise the following challenge: Any theoretical claim that trade policy lies at the heart of postwar growth performance in these two regions must also explain why high tariffs did not appear to dampen the Latin belle époque and why low tariffs did not ignite an Asian miracle before 1914. 


\section{References}

J. E. Anderson (1998), “Trade Restrictiveness Benchmarks,” Economic Journal 108 (July): 111125 .

J. E. Anderson and J. P. Neary (1994), "Measuring the Restrictiveness of Trade Policy," The World Bank Economic Review 8 (May): 151-69.

K. Bagwell and R. W. Staiger (2000), AGATT-Think, @ NBER Working Paper 8005, National Bureau of Economic Research, Cambridge, Mass.

S. L. Baier and J. H. Bergstrand (2001), "The Growth of World Trade: Tariffs, Transport Costs, and Income Similarity," Journal of International Economics 53, 1: 1-27.

C. Blattman, M. A. Clemens and J. G. Williamson (2002), "Who Protected and Why? Tariffs the World Around 1870-1913." Paper presented to the Conference on the Political Economy of Globalization, Dublin (August 29-31).

L. Brandt (1993), "Interwar Japanese Agriculture: Revisionist Views on the Impact of the Colonial Rice Policy and Labor-Surplus Hypothesis." Explorations in Economic History 30, no. 3: 259-93.

M. A. Centeno (1997), ABlood and Debt: War and Taxation in Nineteenth-Century Latin America,@ American Journal of Sociology 102 (May): 1565-605.

M. A. Clemens, K. H. O’Rourke and J. G. Williamson (ongoing), "What Determined High Tariffs in the European Periphery 1870-1940?"

M. A. Clemens and J. G. Williamson (2002), "Why Did the Tariff-Growth Correlation Reverse after 1950?” NBER Working Paper 9181, National Bureau of Economic Research, Cambridge, Mass. (September).

J. H. Coatsworth and J. G. Williamson (2002), "The Roots of Latin American Protectionism: Looking Before the Great Depression," NBER Working Paper 8999, National Bureau of Economic Research, Cambridge, Mass. (June).

V. Corbo (1992), "Development Strategies and Policies in Latin America: A Historical Perspective," International Center for Economic Growth, Occasional Paper No. 22 (April): 16-48.

C. Diaz-Alejandro (1984), "Latin America in the 1930s," in R. Thorp (ed.), Latin America in the 1930s (New York: Macmillan): 17-49.

A. Dixit (1987), AStrategic Aspects of Trade Policy,@ in T. F. Bewley (ed.), Advances in Economic Theory: Fifth World Congress (New York: Cambridge University Press).

C. Howe (1996), The Origins of Japanese Trade Supremacy (Chicago: University of Chicago Press).

J. R. Huber (1971), "Effect on Prices of Japan's Entry into World Commerce after 1858." Journal of Political Economy 79, no. 3: 614-28.

J. C. Ingram (1971), Economic Change in Thailand 1850-1970 (Stanford, California: Stanford University Press).

K. H. Kang and M. S. Cha (1996), "Imperial Policy or World Price Shocks? Explaining Interwar Korean Living Standards." Paper presented to the Conference on East and Southeast Asian Economic Change in the Long Run, Honolulu, Hawaii (April). 
P. H. Lindert and J. G. Williamson (2002), "Does Globalization Make the World More Unequal?" in M. Bordo, A. M. Taylor and J. G. Williamson (eds.), Globalization in Historical Perspective (Chicago: University of Chicago Press and NBER).

W. W. Lockwood (1968), The Economic Development of Japan: Growth and Structural Change, Expanded Edition (Princeton: Princeton University Press).

D. Mares (2001), Violent Peace: Militarized Interstate Bargaining In Latin America (New York. Columbia University Press).

K. H. O'Rourke and J. G. Williamson (1999), Globalization and History (Cambridge, Mass.: MIT Press).

K. H. O'Rourke and J. G. Williamson (2002), "After Columbus: Explaining the European Overseas Trade Boom 1500-1800," Journal of Economic History 62 (June): 417-56.

R. Owen (1993), The Middle East in the World Economy 1800-1914 (London: Tauris).

C. F. Remer (1926), The Foreign Trade of China (Shanghai: The Commercial Press Ltd.).

R. Rogowski (1989), Commerce and Coalitions: How Trade Effects Domestic Political Arrangements (Princeton, N.J.: Princeton University Press).

J. D. Sachs and A. Warner (1995), "Economic Reform and the Process of Global Integration," Brookings Papers on Economic Activity, I (Washington, D.C.: Brookings Institution).

A. Taylor (1998), "On the Costs of Inward-Looking Development: Price Distortions, Growth, and Divergence in Latin America," Journal of Economic History 58 (March): 1-28.

J. G. Williamson (2002), "Land, Labor and Globalization in the Third World, 1870-1940," Journal of Economic History 62 (March): 55-85.

Y. Yasuba (1996), "Did Japan Ever Suffer from a Shortage of Natural Resources Before World War II?” Journal of Economic History 56, no. 3 (1996): 543-60. 


\section{Table 1 Tariff Autonomy}

Over the years spanning 1870 to 1938 , the periods during which

countries are deemed to have autonomy over setting tariff rates were:

$\begin{array}{ll}\text { Argentina } & \text { All } \\ \text { Australia } & \text { All } \\ \text { Austria/Austria-Hungary } & \text { All } \\ \text { Brazil } & \text { All } \\ \text { Burma } & \text { None } \\ \text { Canada } & \text { All } \\ \text { Ceylon } & \text { None } \\ \text { Chile } & \text { All } \\ \text { China } & 1929 \text { and after } \\ \text { Colombia } & \text { All } \\ \text { Cuba } & 1899 \text { and after } \\ \text { Denmark } & \text { All } \\ \text { Egypt } & \text { Before } 1882 \\ \text { France } & \text { All } \\ \text { Germany } & \text { All except 1919-1925 } \\ \text { Greece } & \text { All } \\ \text { India } & \text { None } \\ \text { Indonesia } & \text { None } \\ \text { Italy } & \text { All } \\ \text { Japan } & 1900 \text { and after } \\ \text { Mexico } & \text { All } \\ \text { New Zealand } & \text { All } \\ \text { Norway } & 1906 \text { and after } \\ \text { Peru } & \text { All } \\ \text { Philippines } & \text { None } \\ \text { Portugal } & \text { All } \\ \text { Russia/USSR } & \text { All } \\ \text { Serbia/Yugoslavia } & 1878 \text { and after } \\ \text { Spain } & \text { All } \\ \text { Sweden } & \text { All } \\ \text { Thailand } & 1891 \text { and after } \\ \text { Turkey } & \text { All except 1919-1923 } \\ \text { United Kingdom } & \text { All } \\ \text { United States } & \text { All } \\ \text { Uruguay } & \end{array}$


Table 2

Correlation between Tariffs in Colonies and Colonial Master

$\begin{array}{lcccc}\begin{array}{l}\text { Country's } \\ \text { tariff as } \\ \text { dependent var. }\end{array} & \text { Egypt } & \text { Burma } & \text { Ceylon } & \text { India } \\ \text { Time Period } & \mathbf{1 8 6 5 - 1 9 4 5} & \mathbf{1 8 6 5 - 1 9 4 5} & \mathbf{1 8 6 5 - 1 9 4 5} & \mathbf{1 8 6 5 - 1 9 4 5} \\ & & & & \\ \text { UK Tariffs } & 0.607 & 0.672 & 0.493 & 0.893 \\ & 6.65 & 8.62 & 17.5 & 16.5 \\ & \mathbf{0 . 5 8 7} & \mathbf{0 . 6 8 5} & \mathbf{0 . 8 8 6} & \mathbf{0 . 8 7 4}\end{array}$

Spain Tariffs

$-0.0807$

$-0.456$

$\mathbf{- 0 . 0 7 9 1}$

USA Tariffs

$\begin{array}{cc} & 0.870 \\ & 10.2 \\ & \mathbf{0 . 8 3 9} \\ & \\ 11.4 & -2.16 \\ 3.49 & -1.47 \\ & \\ 35 & 46 \\ 0.00630 & 0.704\end{array}$

OLS regressions. t-statistics are in italics and standardized coefficients are in bold below each coefficient 
Table 3 Regional Summary of Tariff Levels, 1870-1913

Latin America ${ }^{1}$

$\begin{array}{lccccc} & \text { Mean } & \text { Std. Dev. } & \text { Min } & \text { Max } & \text { Observations } \\ & & & & & \\ \text { overall } & 27.0 & 8.76 & 9.7 & 58.2 & \mathrm{~N}=341 \\ \text { between } & & 6.84 & & & \text { Groups }=8 \\ \text { within } & & 6.04 & & & \mathrm{~T}=43\end{array}$

$\operatorname{Asia}^{2}$

Mean Std. Dev. Min Max Observations

$\begin{array}{llllll}\text { overall } & 7.04 & 4.29 & 1.78 & 23.5 & \mathrm{~N}=440 \\ \text { between } & & 3.43 & & & \text { Groups }=10 \\ \text { within } & & 2.79 & & & \mathrm{~T}=44\end{array}$

East $\mathbf{A s i a}^{3}$

$\begin{array}{lccccc} & \text { Mean } & \text { Std. Dev } & \text { Min } & \text { Max } & \text { Observations } \\ \text { overall } & 6.70 & 4.80 & 1.78 & 23.5 & \mathrm{~N}=220 \\ \text { between } & & 4.13 & & & \text { Groups }=5 \\ \text { within } & & 3.05 & & & \mathrm{~T}=44\end{array}$

${ }^{1}$ Argentina, Brazil, Chile, Colombia, Cuba, Mexico, Peru, Uruguay. ${ }^{2}$ Burma, China, Ceylon, Egypt, India, Indonesia, Japan, Philippines, Siam, Turkey. ${ }^{3}$ China, Indonesia, Japan, Philippines, Siam. 
Table 4 Average Tariff Levels by Period

\section{0-1899 1900-1913 1919-1938}

$\begin{array}{lccc}\text { Argentina } & 26.1 & 23.4 & 18.0 \\ \text { Brazil } & 34.5 & 40.0 & 23.4 \\ \text { Chile } & 19.4 & 18.3 & 22.1 \\ \text { Colombia } & 33.5 & 47.4 & 29.3 \\ \text { Cuba } & 22.5 & 25.6 & 26.2 \\ \text { Mexico } & 16.6 & 21.9 & 21.2 \\ \text { Peru } & 32.4 & 23.2 & 16.3 \\ \text { Uruguay } & 29.7 & 33.3 & 19.6 \\ & & & \\ \text { China } & 3.2 & 3.3 & 11.3 \\ \text { Indonesia } & 4.9 & 5.2 & 10.0 \\ \text { Japan } & 6.2 & 7.7 & 5.9 \\ \text { Philippines } & 10.3 & 21.2 & 8.1 \\ \text { Siam } & 3.6 & 7.4 & 15.1 \\ & & & \\ \text { Burma } & 4.0 & 11.3 & 22.5 \\ \text { Ceylon } & 6.2 & 7.3 & 13.3 \\ \text { Egypt } & 11.0 & 14.2 & 26.3 \\ \text { India } & 3.4 & 4.7 & 17.3 \\ \text { Turkey } & 7.4 & 9.5 & 30.7\end{array}$

Tariffs are expressed as total import duties collected divided by total imports (\%). 
Table 5 Why Were Tariffs Higher in Latin America than in Asia?

Dependent variable: $\ln \left(\right.$ Own Tariff ${ }^{1}$ )

Sample: 35 Countries ${ }^{2}$, 1870-1913

Panel between effects estimator
(1)
(2)
(3)
(4)
(5)

(6)

\begin{tabular}{|c|c|c|c|c|c|c|}
\hline $\ln ($ Exports/GDP) & $\begin{array}{l}-0.398 \\
(1.68)\end{array}$ & $\begin{array}{l}-0.195 \\
(0.92)\end{array}$ & $\begin{array}{l}-0.384 \\
(1.60)\end{array}$ & & $\begin{array}{l}-0.410 \\
(1.62)\end{array}$ & \\
\hline $\ln \left(\mathrm{GDP} /\right.$ capita $\left.^{3}\right)$ & $\begin{array}{l}-0.421 \\
(1.44)\end{array}$ & $\begin{array}{l}-0.524 \\
(1.71)\end{array}$ & $\begin{array}{l}-0.506 \\
(1.79)^{*}\end{array}$ & $\begin{array}{l}-0.533 \\
(1.82)^{*}\end{array}$ & & \\
\hline $\ln$ (Population) & $\begin{array}{c}-0.477 \\
(3.27)^{* * *}\end{array}$ & $\begin{array}{c}-0.430 \\
(3.13)^{* * *}\end{array}$ & $\begin{array}{c}-0.612 \\
(3.65)^{* * *}\end{array}$ & $\begin{array}{c}-0.384 \\
(4.17)^{* * *}\end{array}$ & $\begin{array}{c}-0.605 \\
(3.41)^{* * *}\end{array}$ & $\begin{array}{c}-0.359 \\
(3.74)^{* * *}\end{array}$ \\
\hline $\ln \left(\right.$ Partner Tariff $\left.{ }^{4}\right)$ & $\begin{array}{c}0.436 \\
(2.31)^{* *}\end{array}$ & $\begin{array}{c}0.505 \\
(2.56)^{* *}\end{array}$ & $\begin{array}{c}0.445 \\
(2.38)^{* *}\end{array}$ & $\begin{array}{c}0.407 \\
(2.11)^{* *}\end{array}$ & $\begin{array}{c}0.438 \\
(2.21)^{* *}\end{array}$ & $\begin{array}{c}0.397 \\
(1.94)^{*}\end{array}$ \\
\hline $\ln \left(\right.$ Effective Dist $\left.{ }^{5}\right)$ & $\begin{array}{l}0.086 \\
(0.98)\end{array}$ & $\begin{array}{c}0.141 \\
(1.44)\end{array}$ & $\begin{array}{r}-0.059 \\
(0.47)\end{array}$ & $\begin{array}{l}0.029 \\
(0.25)\end{array}$ & $\begin{array}{r}-0.092 \\
(0.70)\end{array}$ & $\begin{array}{l}0.001 \\
(0.01)\end{array}$ \\
\hline $\ln \left(\right.$ Railway Miles $\left.{ }^{6}\right)$ & $\begin{array}{c}0.190 \\
(2.06)^{*}\end{array}$ & $\begin{array}{l}0.141 \\
(1.70)\end{array}$ & $\begin{array}{c}0.386 \\
(2.73)^{* *}\end{array}$ & $\begin{array}{c}0.227 \\
(2.16)^{* *}\end{array}$ & $\begin{array}{c}0.388 \\
(2.60)^{* *}\end{array}$ & $\begin{array}{c}0.219 \\
(1.97)^{*}\end{array}$ \\
\hline $\ln \left(\right.$ Schooling $\left.^{7}\right)$ & $\begin{array}{c}-0.117 \\
(0.70)\end{array}$ & $\begin{array}{l}0.097 \\
(0.53)\end{array}$ & $\begin{array}{r}-0.264 \\
(1.08)\end{array}$ & $\begin{array}{r}-0.037 \\
(0.18)\end{array}$ & $\begin{array}{l}-0.475 \\
(2.08)^{*}\end{array}$ & $\begin{array}{l}-0.244 \\
(1.32)\end{array}$ \\
\hline $\ln \left(\right.$ Urbanization $\left.^{8}\right)$ & $\begin{array}{l}0.174 \\
(1.18)\end{array}$ & $\begin{array}{l}0.082 \\
(0.53)\end{array}$ & $\begin{array}{l}0.292 \\
(1.67)\end{array}$ & $\begin{array}{l}0.138 \\
(0.91)\end{array}$ & $\begin{array}{l}0.239 \\
(1.32)\end{array}$ & $\begin{array}{l}0.070 \\
(0.45)\end{array}$ \\
\hline Tariff Autonomy $^{9}$ & $\begin{array}{c}0.760 \\
(2.61)^{* *}\end{array}$ & $\begin{array}{c}0.618 \\
(2.10)^{* *}\end{array}$ & $\begin{array}{c}0.912 \\
(2.84)^{* *}\end{array}$ & $\begin{array}{c}0.795 \\
(2.44)^{* *}\end{array}$ & $\begin{array}{c}0.843 \\
(2.50)^{* *}\end{array}$ & $\begin{array}{c}0.713 \\
(2.10)^{* * *}\end{array}$ \\
\hline Inflation & & & $\begin{array}{c}-0.030 \\
(0.39)\end{array}$ & $\begin{array}{l}0.034 \\
(0.50)\end{array}$ & $\begin{array}{l}-0.037 \\
(0.47)\end{array}$ & $\begin{array}{l}0.030 \\
(0.43)\end{array}$ \\
\hline Inflation Squared & & & $\begin{array}{c}0.003 \\
(2.10)^{*}\end{array}$ & $\begin{array}{c}0.002 \\
(1.43)\end{array}$ & $\begin{array}{c}0.003 \\
(2.07)^{*}\end{array}$ & $\begin{array}{c}0.002 \\
(1.39)\end{array}$ \\
\hline Constant & $\begin{array}{c}5.435 \\
(3.14)^{* * *}\end{array}$ & $\begin{array}{c}4.989 \\
(2.92)^{* * *}\end{array}$ & $\begin{array}{c}7.030 \\
(3.83)^{* * *}\end{array}$ & $\begin{array}{c}5.870 \\
(3.34)^{* * *}\end{array}$ & $\begin{array}{c}5.261 \\
(3.22)^{* * *}\end{array}$ & $\begin{array}{c}3.918 \\
(2.67)^{* *}\end{array}$ \\
\hline Observations & 1,528 & 1,174 & 1,174 & 1,174 & 1,174 & 1,174 \\
\hline No. countries & 35 & 30 & 30 & 30 & 30 & 30 \\
\hline R-Squared & 0.655 & 0.717 & 0.784 & 0.753 & 0.745 & 0.710 \\
\hline
\end{tabular}

Absolute value of t-statistics are in parentheses below coefficient estimates. * significant at $10 \%$; ** significant at $5 \%$; ** significant at $1 \% .{ }^{1}$ Import duties over imports. ${ }^{2}$ Argentina, Australia, Austria-Hungary, Brazil, Burma, Canada, Ceylon, Chile, China,

Colombia, Cuba, Denmark, Egypt, France, Germany, Greece, India, Indonesia, Italy, Japan, Mexico, New Zealand, Norway, Peru, Philippines, Portugal, Russia, Serbia, Siam, Spain, Sweden, Turkey, United Kingdom, United States, and Uruguay. ${ }^{3}$ In 1990 US\$. ${ }^{4}$ Index of average tariff levels in top 5 trading partners weighted by exports going to that partner. ${ }^{5}$ Product of average physical distance to top 5 trading partners (principal city to principal city) weighted by exports going to that country, and transportation cost index. ${ }^{6}$ Miles of railway trunk line in country. ${ }^{7}$ Fraction of the population below the age of 15 that is enrolled in primary school. ${ }^{8}$ Fraction of the population living in agglomerations of greater than 50,000 people. ${ }^{9}$ Indicator variable taking the value 1 if country has the freedom to set own tariff levels independently, or 0 if it does not. 
Table 6 Which Regressors from Table 5 Can Account for the Difference in Tariffs between Latin America and Asia before 1914?

$\begin{array}{ccc} & \begin{array}{c}\text { Average } \\ \text { regressor values: } \\ \text { Latin }\end{array} & \text { Fraction of regional difference explained: } \\ \text { Coefficient estimates from Table } 5 & \text { America } & \text { Asia }\end{array} \quad \delta=\frac{\text { Coeff. } \times \text { (L.Am. avg. }- \text { Asia avg.) }}{\text { (L.Am. tariff }- \text { Asia tariff) }}$

(2)

(3)

(4) (5)

(6)

(7) (8)

$\left(1^{\prime}\right)$

$\left(2^{\prime}\right)$

$\left(3^{\prime}\right)$

$\left(4^{\prime}\right)$

$\left(5^{\prime}\right)$

$\left(6^{\prime}\right)$

$\ln$ (Exports/GDP)

$\begin{array}{llll}-0.398 & -0.195 & -0.384 & -0.410\end{array}$

$\ln (\mathrm{GDP} /$ capita $)$

$\begin{array}{llll}-0.421 & -0.524 & -0.506 & -0.533\end{array}$

$-1.94-2.96$

$\begin{array}{lll}-0.28 & -0.14 & -0.27\end{array}$

$-0.29$

$\ln$ (Population)

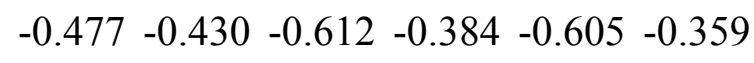

$\begin{array}{ll}7.16 & 6.59\end{array}$

$\begin{array}{llll}-0.17 & -0.21 & -0.20 & -0.21\end{array}$

$\ln$ (Partner Tariff)

$\begin{array}{llllll}0.436 & 0.505 & 0.445 & 0.407 & 0.438 & 0.397\end{array}$

$8.18 \quad 10.0$

$\begin{array}{llll}0.62 & 0.56 & 0.79 & 0.50\end{array}$

$2.71 \quad 2.14$

$0.17 \quad 0.20$

0.17

0.16

$\ln$ (Effective Dist.)

$\begin{array}{lllllll}0.086 & 0.141 & -0.059 & 0.029 & -0.092 & 0.001\end{array}$

$8.09 \quad 7.99$

$\begin{array}{lll}0.01 & 0.01 & 0.00\end{array}$

$7.20 \quad 5.72$

0.20

$\ln$ (Railway Miles)

$\begin{array}{llllll}0.190 & 0.141 & 0.386 & 0.227 & 0.388 & 0.219\end{array}$

$6.96 \quad 6.11$

$\begin{array}{ll}-0.07 & 0.06\end{array}$

$0.40 \quad 0.2$

$\begin{array}{lll}0.00 & -0.01 & 0.00\end{array}$

$\ln$ (Schooling)

$\begin{array}{llllll}-0.117 & 0.097 & -0.264 & -0.037 & -0.475 & -0.244\end{array}$

$4.55 \quad 3.94$

$0.07 \quad 0.03$

$-0.16-0.02$

$\begin{array}{ll}0.40 & 0.23\end{array}$

$\ln$ (Urbanization)

$\begin{array}{llllll}0.174 & 0.082 & 0.292 & 0.138 & 0.239 & 0.070\end{array}$

$0.918 \quad 0.211$

0.3

$\begin{array}{llll}0.12 & 0.06 & 0.10 & 0.03\end{array}$

$\begin{array}{llllll}0.760 & 0.618 & 0.912 & 0.795 & 0.843 & 0.713\end{array}$

$2.06 \quad 0.486$

Inflation

$\begin{array}{lllll}-0.030 & 0.034 & -0.037 & 0.030\end{array}$

96.9224

$\begin{array}{llll}0.45 & 0.39 & 0.41 & 0.35\end{array}$

$\begin{array}{llll}-0.03 & 0.04 & -0.04 & 0.03\end{array}$

Inflation Squared

$\begin{array}{llll}0.003 & 0.002 & 0.003 & 0.002\end{array}$

$3.24 \quad 1.80$

$\begin{array}{llll}-0.27 & -0.18 & -0.27 & -0.18\end{array}$

$\ln$ (Own Tariff)

Coefficient estimates in columns (1) through (6) are taken directly from Table 5. Columns (7) and (8) show the average value of the underlying regressor before 1914 in Latin America and Asia, respectively, where Latin America includes Argentina, Brazil, Chile, Colombia, Cuba, Mexico, Peru, and Uruguay, and Asia includes Burma, China, Ceylon, Egypt, India, Indonesia, Japan, Philippines, Siam, and Turkey. Columns (1') through (6') take the difference between columns (7) and (8), multiply this difference by the corresponding coefficient from one of the first six columns, and divide by the difference between average $\ln ($ Own Tariff) in Latin America and average $\ln (\mathrm{Own}$ Tariff) in Asia. This value $\delta$ can be interpreted as the fraction of the difference between the two regions' tariffs that is explained by each regressor. Since tariffs were higher in Latin America, a negative value of $\delta$ suggests that the regressor cannot explain the observed difference; a large positive value suggests it can. 
Figure 1

\section{British tariffs vs. tariffs in the Empire}

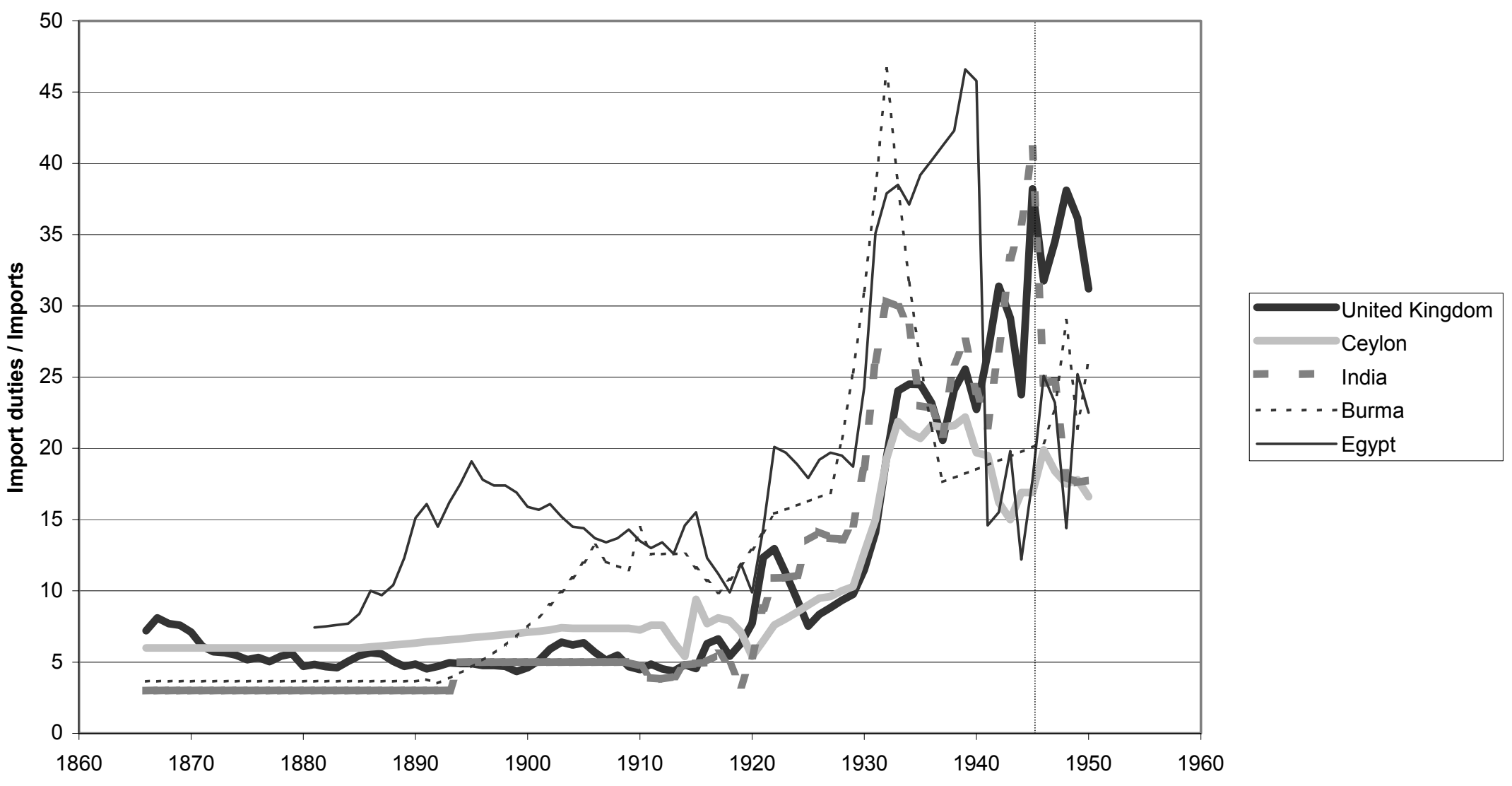




\section{Figure 2}

Filipino tariffs vs. Spanish and American tariffs

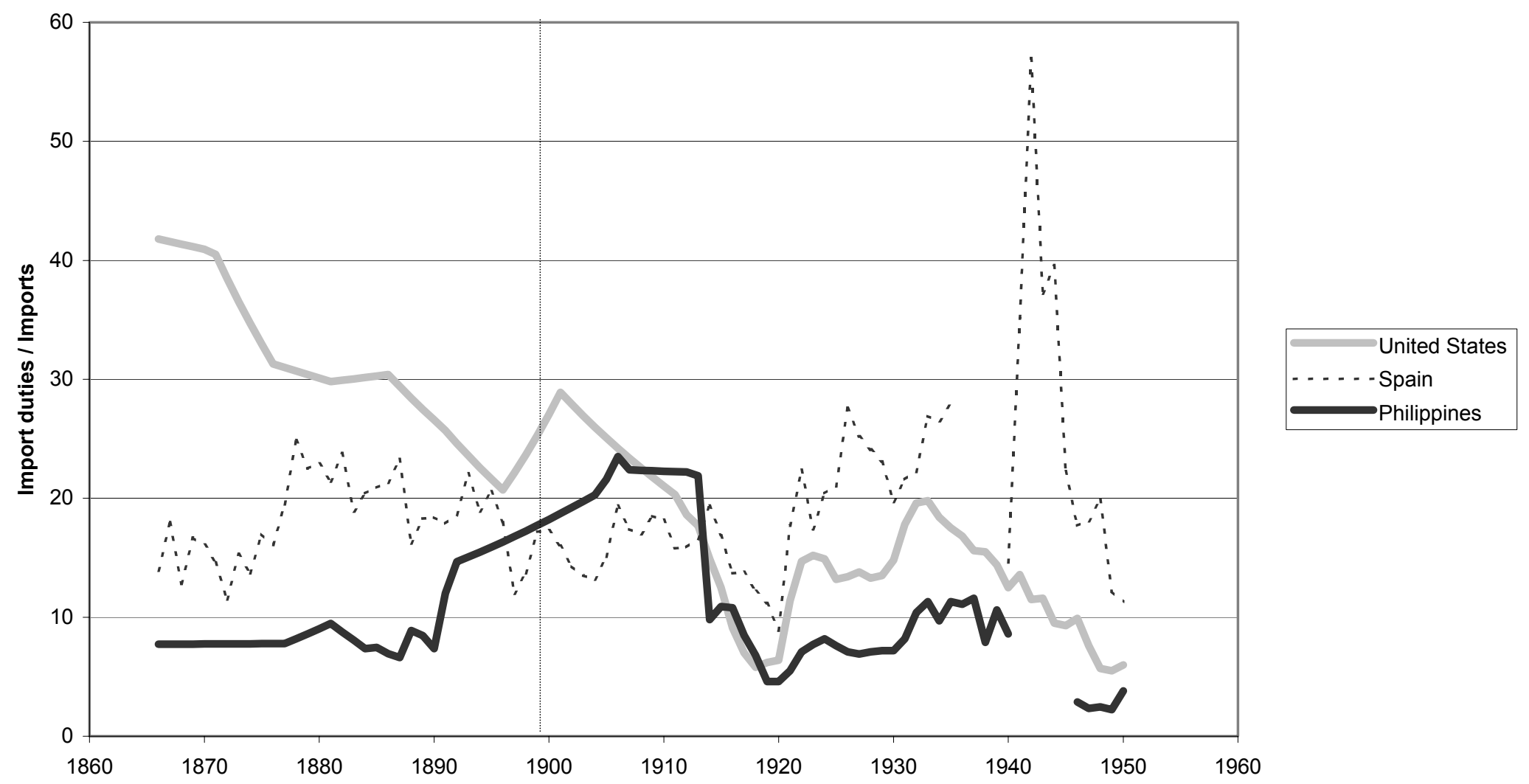




\section{Figure 3}

Average and standard deviation of tariff levels: Colonies vs. Non-Colonies in Asia

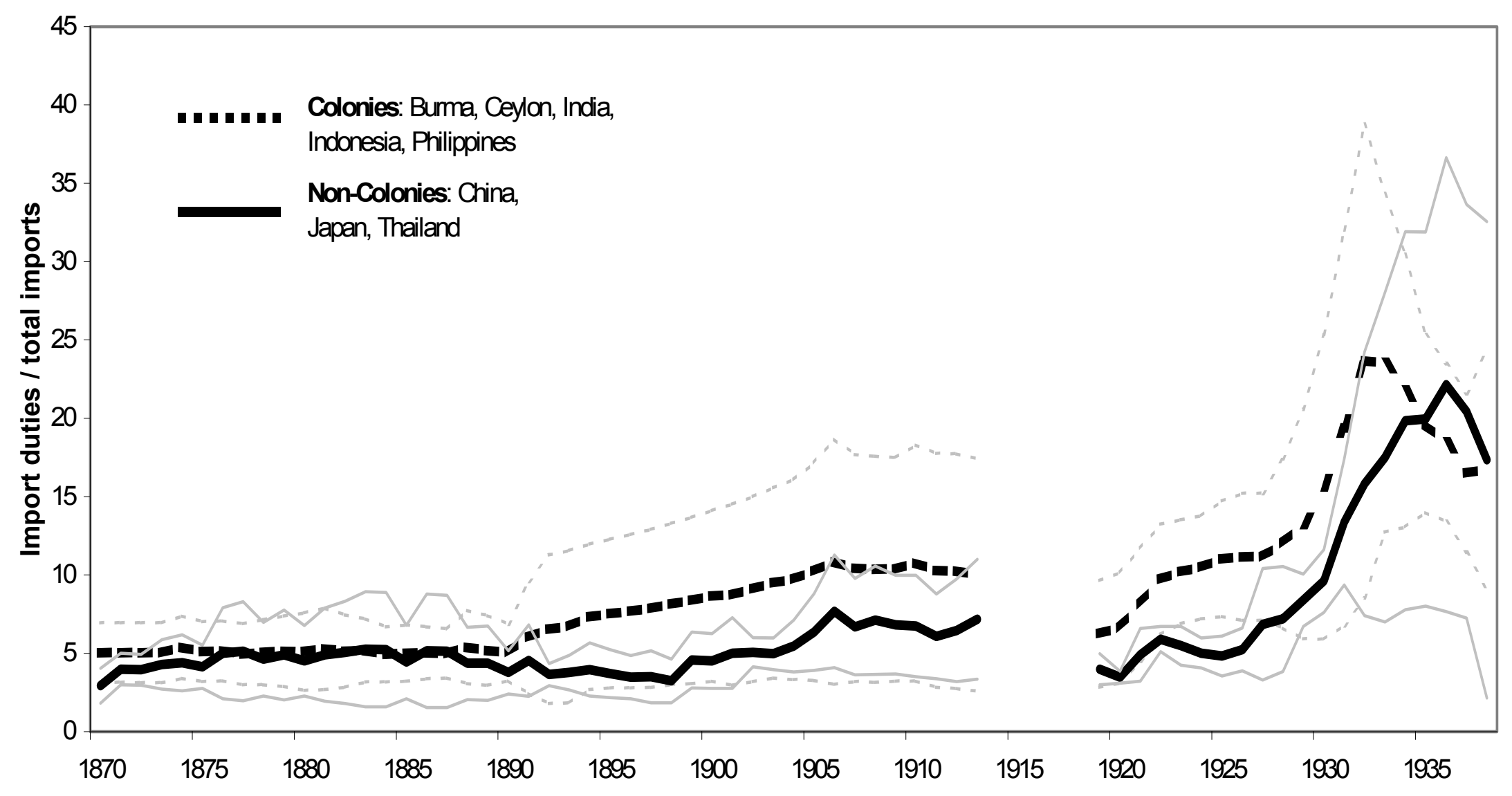




\section{Figure 4}

Regional average and standard deviation of tariff levels:

Latin America vs. Asia

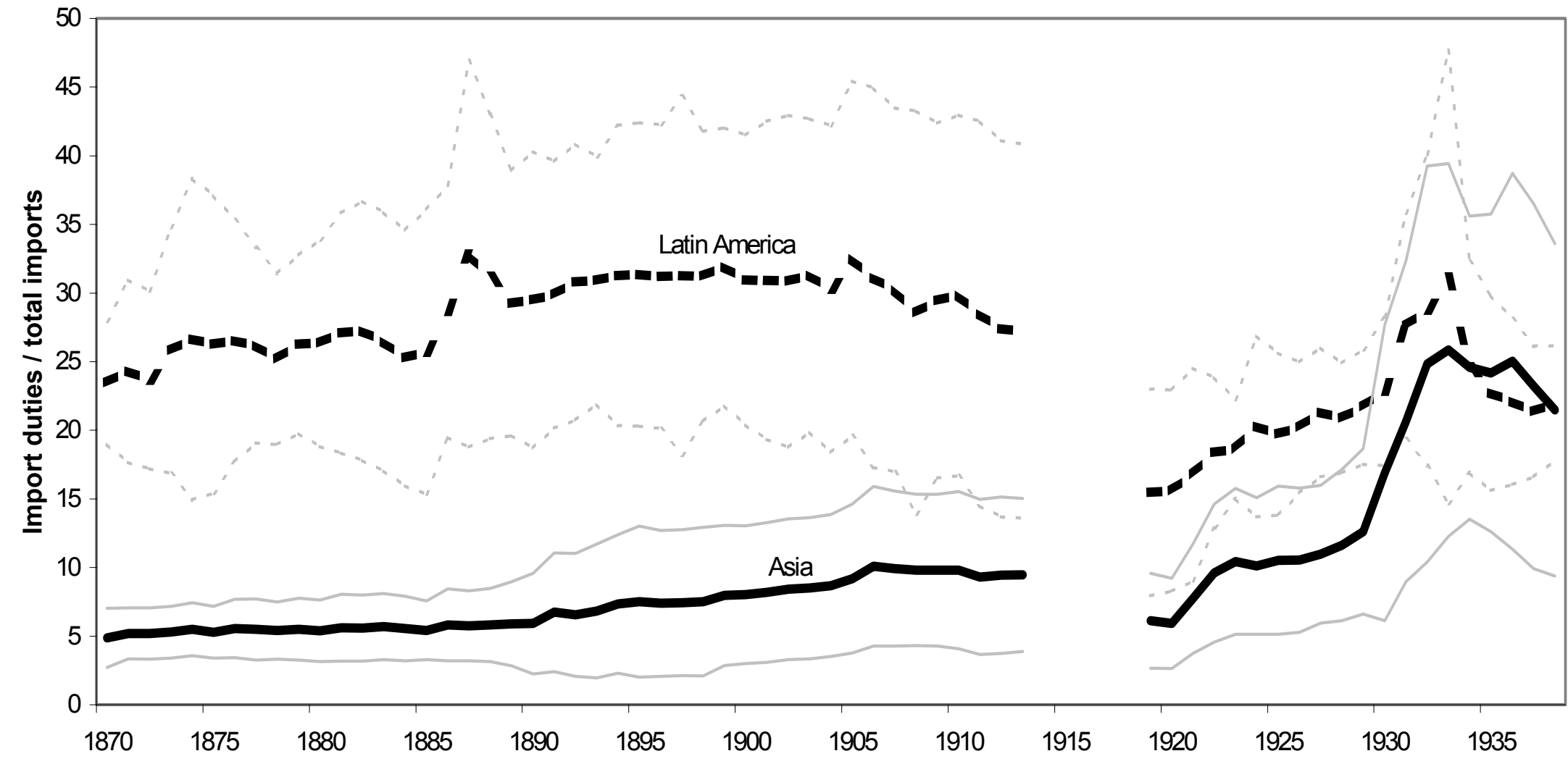




\section{Figure 5}

Regional average and standard deviation of GDP/capita: Latin America vs. Asia

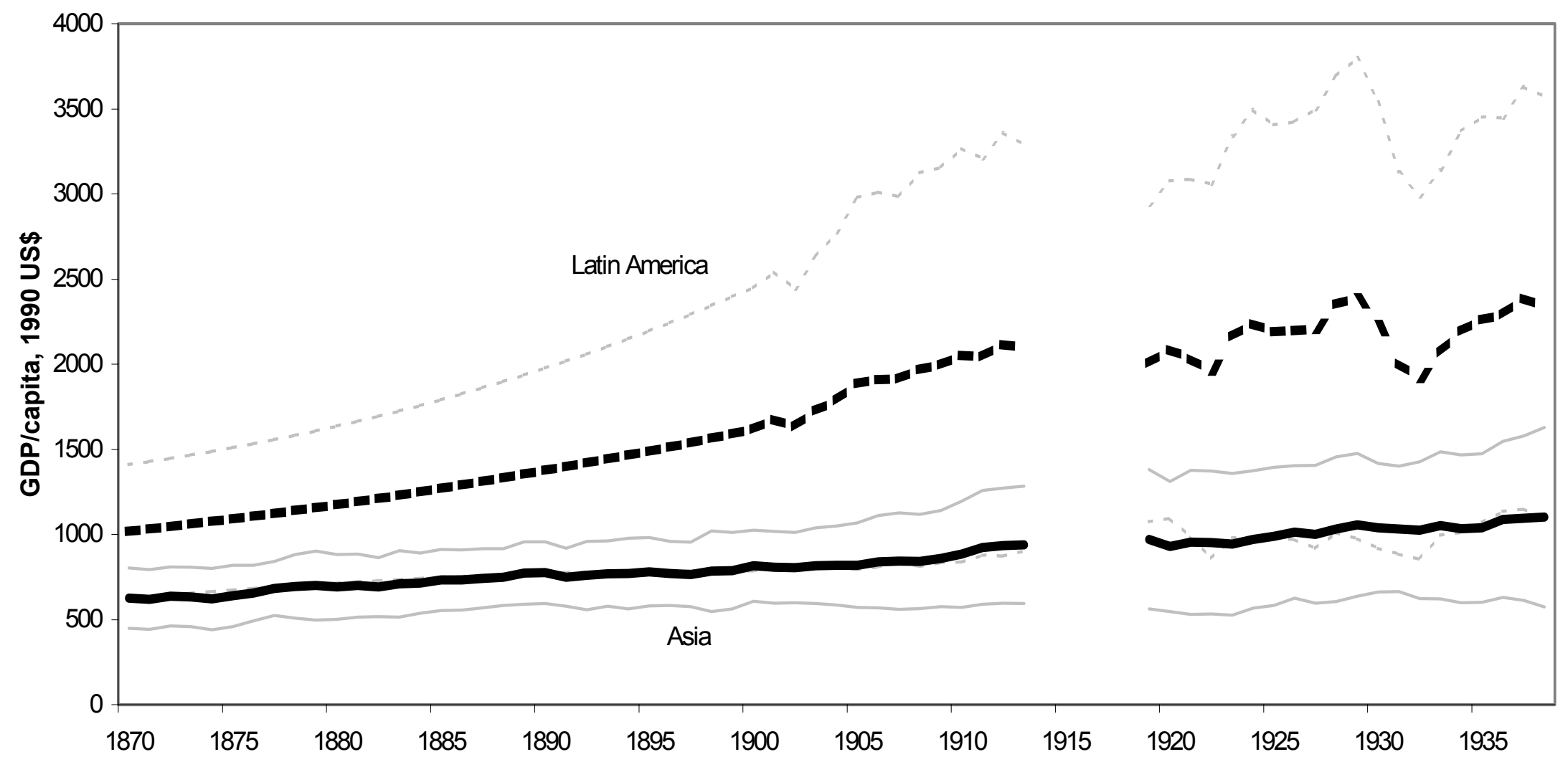


Figure 6 The Tariff-Growth Correlation in the Years Before World War I

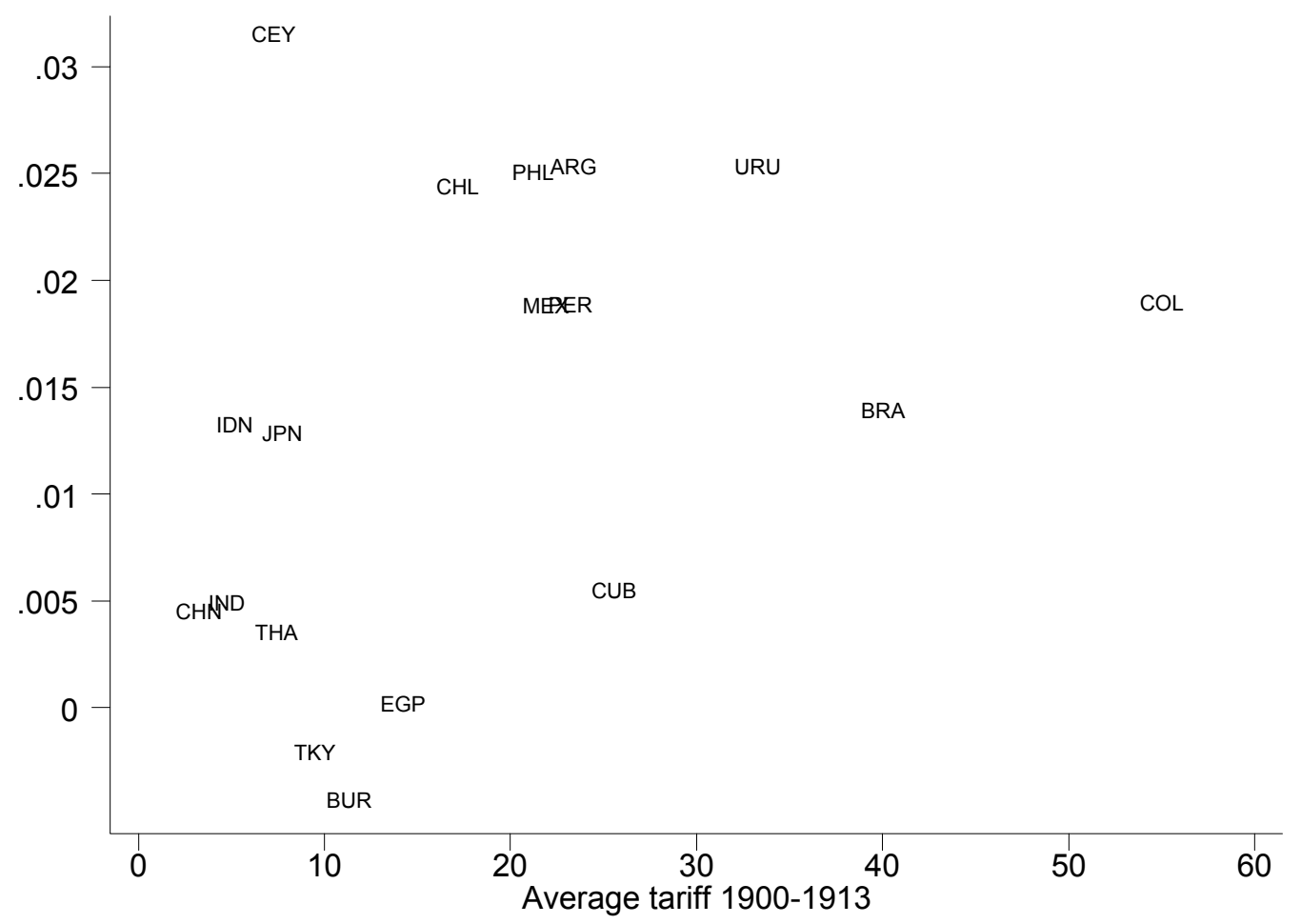

